\title{
Beauty, utility and Christian civilisation: war memorials and the Church of England, 1940-47 ${ }^{1}$
}

Peter Webster (Institute of Historical Research, University of London)

[This is a pre-copy-editing, author-produced PDF of an article accepted for publication in Forum for Modern Language Studies following peer review. The definitive publisher-authenticated version [Forum for Modern Language Studies 44:2 (2008) 199-211] is available online at: http://fmls.oxfordjournals.org/cgi/content/abstract/44/2/199. ]

The years following the end of the First World War saw an effusion of memorials to that war, to the extent that scarcely a village, school or regiment was without a monumental commemoration of its fallen. The last two decades has seen a blooming in scholarship on memorialisation, focussed particularly on, although not confined to, the Great War. ${ }^{2}$ The impression that might be gained from a journey through much of rural England is that the stone cross, placed by the village green, was the predominant form of memorial chosen by English communities after 1918. Despite the preponderance of such monuments amongst those memorials that were actually built, some of this recent scholarship has suggested that this has obscured the debates that took place over the appropriate form that memorials should take. For rural Sussex, Keith Grieves has described vigorous contests between the newly-empowered men returning from the front and the more established local elites of parson and aristocracy over the very purpose of memorialisation. ${ }^{3}$ Also disputed was the claim of

\footnotetext{
${ }^{1}$ The author is indebted to Andrew Chandler, Matthew Grimley, Derek Keene, Ian Jones and Elizabeth Williamson for their comments on drafts of this article.

${ }^{2}$ General studies include: Alan Borg, War Memorials. From antiquity to the present (London, Leo Cooper, 1991); Alex King, Memorials of the Great War in Britain. The symbolism and politics of remembrance (Oxford, Berg, 1998); Jay Winter, Sites of memory, sites of mourning. The Great War in European cultural history (Cambridge, Cambridge University Press, 1995) pp.78-116.

${ }^{3}$ Grieves, 'Common meeting places and the brightening of rural life: local debates on village halls in Sussex after the First World War' Rural History 10, 2 (1999) 171-92. See also Jonathan Black,

'Thanks for the memory: war memorials, spectatorship and the trajectories of commemoration 1919-
} 
the parish church as the iconic centre of the village, and its preeminence over both the dissenting churches and more neutral communal spaces as the natural place for a memorial. ${ }^{4}$ As well as questions about whose purposes memorials were to serve, and where they should be placed, questions of the relationship between form and function were also raised. Several schemes were considered for Cambridge, which between them epitomised the three poles between which discussion oscillated. Should a civic memorial be within the precincts of the church (as the proposal for Ely cathedral envisioned) ? Jay Winter has suggested that amongst the European nations the British were most disposed towards 'useful' memorial projects, and the proposal for new nurses' accommodation at Addenbrooke's Hospital was typical of such a scheme, designed for the use of those left behind. 5 Thirdly, should memorials, as in the case of the statue of a returning soldier near Cambridge railway station, be intentionally 'useless' interruptions into everyday spaces; monuments with the purpose of arresting the passing gaze and prompting recollection ? 6 Advocates could be found for all three types of memorial, and of schemes which combined elements of each. ${ }^{7}$

If advocates of monumental memorials had by and large won out after 1918, recent scholarship has suggested that, in contrast, the years after the second global conflict of the century were characterised by a much greater indifference, and indeed hostility, among the survivors of that conflict towards the building of further monuments in stone. Nick Hewitt has suggested that this 'sceptical generation' desired 'practical' or 'useful' memorials, such as playing fields, community

2001 ' in Nicholas J. Saunders (ed.), Matters of Conflict. Material culture, memory and the First World War (London, Routledge, 2004) pp.134-48.

${ }^{4}$ Nick Mansfield, 'Class conflict and village war memorials, 1914-24', Rural History 6, 1 (1995) 6787; in particular pp.79-80; King, Memorials pp.88-9. For a survey of the reactions of the Church of England to memorialisation, see Alan Wilkinson, The Church of England and the First World War (London, SPCK, 1978), 294-310.

${ }^{5}$ Winter, Sites of Memory p.97.

${ }^{6}$ K. S. Inglis, 'The Homecoming: the War Memorial monument in Cambridge, England' Journal of Contemporary History 27 (1992) 583-605.

${ }^{7}$ On these debates after 1918, see King, Memorials pp.65-70, 75-85. 
halls or educational scholarships. ${ }^{8}$ For Hewitt and others, the 'artistic establishment', the 'ancient gentlemen' who staffed bodies such as the Imperial War Graves Commission and who generally favoured new monuments, were by 1944 out of touch with a utilitarian public. ${ }^{9}$ Attitudes to the conflict of 1939-45 were, it has been suggested, much more ambivalent than in the years after 1918. Several reasons for this shift in opinion have been suggested, including cynicism about the causation of the war, differing patterns of conscription, the much greater impact on civilians (despite lower casualty figures overall) and the impact of Auschwitz and the atom bomb. ${ }^{10}$ Whatever the underlying causes, the task of systematically assessing popular attitudes to memorials after 1945 is one that has hardly begun, and one for which the source material is relatively scarce. The present article is confined to a consideration of the 'establishment' to which Hewitt refers.

The years towards the end of and immediately after the war saw a great deal of discussion amongst government, artistic bodies, individual artists and craftsmen and the church regarding the proper mode(s) of commemorating the conflict. The Royal Society of Arts (RSA) held a conference and an inquiry to consider the question in April 1944. ${ }^{11}$ The report that issued from that investigation was published by the War Memorials Advisory Council, a body set up by the RSA and presided over by the Admiral of the Fleet, Lord

\footnotetext{
${ }^{8}$ Nick Hewitt, 'A Sceptical Generation? War Memorials and the Collective Memory of the Second World War in Britain, 1945-2000' in Dominik Geppert (ed.), The Postwar Challenge. Cultural, Social and Political Change in Western Europe, 1945-58 Oxford, OUP (for the German Historical Institute) 2003 pp.81-97. This analysis is broadly in line with that of Bob Bushaway, 'The Obligation of Remembrance or the Remembrance of Obligation: society and the memory of World War.' in Peter Liddle, John Bourne, Ian Whitehead (eds), The Great World War 1914-45. Volume 2. The peoples' experience (London, Harper Collins, 2001) pp.489-508.

${ }^{9}$ Hewitt, 'Sceptical Generation' pp.85-7. On the 'ancient gentlemen' see George L. Mosse, 'Two World Wars and the Myth of the War Experience', J. of Contemporary History 21 (1986) 491-513; p.504.

${ }^{10}$ Bushaway, 'Obligation of Remembrance' pp.502-5; Hewitt, 'Sceptical generation' pp.82-5. Mosse, 'Two World Wars' p.505. David Cannadine, 'War and Death, Grief and Mourning in Modern Britain' in Joachim Whaley (ed.), Mirrors of Mortality. Studies in the Social History of Death (London, Europa, 1981) pp.187-242; p.233.

${ }^{11}$ Journal of the Royal Society of Arts (9th June 1944) pp.322-40.
} 
Chatfield. ${ }^{12}$ On the publication of the Council's report, Chatfield was involved in the moving of motions in the House of Lords on the adoption of its findings as national recommendations. ${ }^{13} \mathrm{An}$ examination of the conference of April 1944 gives an indication of the range of interests involved in the question of memorials. The church was represented by the Dean of Westminster, and specifically nonutilitarian thinking on the question was provided by the delegate from the Ecclesiological Society. Amongst those with particular suggestions for 'useful' schemes were the National Playing Fields Association, the Society for the Promotion of Nature Reserves, and the Oswald Stoll Foundation, advocating homes for injured veterans. ${ }^{14}$

The present author has suggested at length elsewhere that there was a great degree of interpenetration and cross-fertilisation between the worlds of art administration, artistic practice and the Church of England as a commissioning body. ${ }^{15}$ The present article will seek to demonstrate that, in debates over the appropriate form for memorials, the Church and other parts of the 'establishment' were in close contact at every turn. The Bishop of Chichester, George Bell, was widely reputed to be the figure within the Church of England with the greatest interest in the rebuilding of what he considered an historic but latterly broken link between the arts and the church. Along with Cosmo Gordon Lang, former Archbishop of Canterbury, Bell intervened in the debate on memorials in the House of Lords in February 1945, and Lord Chatfield was later to attempt to enlist the support of Lang's successor Geoffrey Fisher for a debate in the House

\footnotetext{
${ }^{12}$ War Memorials. A Survey made by a Committee of the Royal Society of Arts.... [London, 1944]

${ }^{13}$ Hansard $134(14 / 2 / 45)$ col.1016-54. Chatfield was to return to the subject of an Imperial Memorial in London in 1947; Hansard 145 (22/1/47) cols. 42-59.

${ }^{14}$ JRSA 9/6/44. The delegates were: P.F.D. de Labilliere (Dean of Westminster); Dudley Daymond (Ecclesiological Society); Sir Noel Curtis-Bennett (National Playing Fields Association); Dr Herbert Smith (Society for the Promotion of Nature Reserves) and W. J. Roberts (Oswald Stoll Foundation.) 15 'The "revival" in the visual arts in the Church of England, c.1935-c.1956' Studies in Church History 44 (forthcoming, 2008). On the relationship between the church and the musical 'establishment', see Ian Jones and Peter Webster, 'Anglican "Establishment" reactions to "pop" church music, 1956c.1990' in Kate Cooper and Jeremy Gregory, eds., Elite and Popular Religion, SCH 42 (Woodbridge, 2006) 429-41, at 430.
} 
in 1947.16 This was, however, no merely reactive commentary. As early as November 1939 Bell had been in correspondence with F.C. Eeles, of the Central Council for the Care of Churches in relation to the issue of memorials that would surely arise. ${ }^{17}$ By 1944 , however, consciousness was growing of a need to formulate firm policy on what one correspondent referred to as the 'war-memorial problem', with the Bishop of Leicester (G.V. Smith) suggesting to Fisher that the issue be discussed formally amongst the Bishops. ${ }^{18}$

It was in the autumn of 1944 that Bell convened a conference at Chichester to discuss the reforging of the link between artists and the church in general, and memorials in particular, and the composition of the list of delegates illustrates the range and depth of Bell's contacts. ${ }^{19}$ Taking part in the specific discussion on memorials was the artist Charles Tennyson, who had also attended the RSA conference earlier in the year, as had another participant, Charles Wheeler, an artist with substantial work to his name on memorials after the First World War. ${ }^{20}$ Bell was also in regular correspondence with Sir Herbert Baker, a former architect of the Imperial War Graves Commission, and with whom Wheeler had worked at Winchester College and on the Indian National Memorial at Neuve-Chapelle. ${ }^{21}$

Further evidence of the place of memorials in Bell's thinking, and of the range of his connections, is the manifesto of the Sussex Churches

\footnotetext{
${ }^{16}$ Hansard 134 cols.1038-46. Chatfield to Fisher 5/1/47 at Lambeth Palace Library [hereafter LPL] MS Fisher 37 ff.336-7. The George Bell Papers, the Geoffrey Fisher Papers and the Fulham Papers (Fisher) are cited by kind permission of the Librarian of Lambeth Palace.

${ }^{17}$ Eeles to Bell 7/11/39, at LPL MS Bell 150 f.37.

${ }^{18}$ R.S.T. Haslehurst (vice-chancellor of Chichester cathedral) to Bell 7/9/44, at LPL MS Bell 151 f.174; Leicester to Fisher 26/4/44 LPL MS Fisher 37 ff.324.

19 'The Church and the Artist', conference at the episcopal palace, September 15th-18th. Notes prepared by Bell, at West Sussex County Record Office [hereafter WSRO] MS Hussey 180. The Hussey Papers are cited by courtesy of the Very Reverend the Dean of Chichester and with acknowledgments to the West Sussex Record Office and the County Archivist. The delegates included artists including Henry Moore and Duncan Grant, critics such as Eric Newton, Dorothy Sayers and T.S. Eliot, and administrators including Sir Eric Maclagan, director of the Victoria \& Albert Museum, and F.C. Eeles of the Central Council for the Care of Churches.

${ }^{20}$ Whittick, War Memorials (London, Country Life, 1946) pp.54, 65-6.

${ }^{21}$ See the correspondence at LPL MS Bell $151 \mathrm{ff} .147-8,175$.
} 
Arts Council, a body set up by Bell in 1942 and which bore many of his hallmarks. ${ }^{22}$ Amongst the members of the founding committee were Charles Wheeler and the architect Edward Maufe, a resident of Sussex and, from January 1944, principal architect of the Imperial War Graves Commission for the United Kingdom. ${ }^{23}$ The aim of the Council was to secure the best of all types of visual art for the churches of Sussex, including 'finely written memorials.' As the chairman Bertram Nicholls put it:

We are convinced that the creation of new works of art by living artists in the service of the Church is of the highest importance; and that a renewal of the association between the Church and the Arts can again be made a potent influence; perhaps the most potent of all influences in re-establishing those moral values without which a stable world can never be created after the war.'

One common note in almost all of the discussion among and produced by this 'establishment' was one of caution against an excessive emphasis on the 'practical' or 'utilitarian'. This focus on the utility of memorials was evident in the debate in the House of Lords on the subject. Lord Winster made reference to the truism that the best possible memorial to the fallen would be 'to ensure good treatment of the men who come back and good treatment of their dependants.' 24 Hospitals and homes, particularly for those who returned from the war permanently disabled, were thus seen to be a perfect embodiment of that sentiment, and even better would be community centres and village halls, especially when providing space for youth activities. Twice in the century the youth of the nation 'have had to go into war for which they must have felt that they had very little responsibility.' It would be surely a great satisfaction to those youth who had fallen if the nation did something for the next generation. ${ }^{25}$

\footnotetext{
${ }^{22}$ Manifesto document at WSRO MS Hussey 180.

${ }^{23}$ Philip Longworth, The Unending Vigil. A history of the Commonwealth War Graves Commission 1917-1967 (London, Constable, 1967) p.179.

${ }^{24}$ Hansard 14/2/45 c. 1026

${ }^{25}$ Ibid., c.1027. On the hopes for British youth after 1945, see Bill Osgerby, Youth in Britain since 1945 (Oxford, Blackwell, 1998) pp.10-14.
} 
Some commentators, whilst acknowledging the groundswell of opinion in favour of 'usefulness', attempted to assert a higher purpose. Lord Chatfield suggested that a monumental memorial might not be useful 'for mere practical purpose, but it has an important value for the mind and character.' Chatfield suggested that, whilst a village hall might well be a thing of beauty if well designed and made, it would be unlikely that 'any project becomes a fitting war memorial merely by attaching the label "war memorial" to it.' A memorial that was not recognisable as such without an explanatory plaque would have failed in its primary purpose. In a 'mainly materialistic age', a national memorial scheme might be an opportunity to demonstrate 'our possession of nobler qualities' since 'things spiritual are essentials in life; are they not what our national character needs to-day, even more, perhaps, than material things ?'26 Arnold Whittick, in by far the most thorough treatment of the whole subject of memorials of the period, also took issue with the type of memorial that was unidentifiable as such within a few short years. Doubt might well be cast on the sincerity of those planning memorials if they were to be treated as an opportunity for 'riding their own hobby-horses.' Thus lists of suggestions from the British Hospitals Association, or schemes from the Council for the Encouragement of Music and Art for the building of art centres were as much the products of particular interests as the local town council in need of a new school or club building. ${ }^{27}$ Particularly unsuitable was the use of such funds to provide facilities that were more properly the duty of the state. Lord Denham had made mention of a proposal to do away with a lengthy waiting list by extending and improving an existing local hospital. ${ }^{28}$ Viscount Esher suggested a new Charing Cross bridge, already a pressing need for several years, perhaps with the names of the fallen recorded on the supporting towers. ${ }^{29}$

\footnotetext{
${ }^{26}$ Preface to Arnold Whittick, War Memorials pp.v-vii.

${ }^{27}$ Whittick, War Memorials p.2.

${ }^{28}$ Hansard (14/2/45) c. 1046

${ }^{29}$ Ibid., c. 1048
} 
In contrast, Lord Lang of Lambeth argued that the 'prevailing utilitarian spirit of the age' was giving rise to a misconception of the purpose of a memorial, and that 'we have to consider not what we would most wish for the living but what we owe to the dead.' Whilst acknowledging the need for halls and community centres, these were things that 'we ought plainly to do for ourselves; they are what we ought plainly to expect the community to do on its own initiative and for its own honour.' The guiding principle ought rather to be 'the association of the war memorial visibly and permanently with those whom we desire to commemorate. ${ }^{30}$ For Whittick, the whole range of parks, hospitals and community centres were indeed essential, but should be provided as a matter of course by the state as part of 'normal social service; but they are not memorials and calling them memorials will not make them so.' 31

This mixture of the pragmatic and the cautiously religious was characteristic of much of the argumentation from non-clergy. Whittick. considering schemes for a national memorial, was able to liken a memorial to the altar in a church: 'it is the centre of devotion and homage, and as seats are provided for the worshippers in a church, so should they be furnished for those who wish to meditate at a sacred national shrine. ${ }^{32}$ Whittick was unprepared, however, to enlarge any further on what he described as the broader 'spiritual purpose' of a memorial, part of the 'poetry of life' which whilst being of no use in the practical sense is perhaps the finest expression of our national life and character. ${ }^{3} 3$

If it was the case that both lay and clerical members of the 'establishment' drew on similar views on utility, and made similar diagnoses of the roots of the common overemphasis on it, it was left to

\footnotetext{
${ }^{30}$ Hansard (14/2/45) c.1037-8.

${ }^{31}$ Whittick War Memorials p.3.

${ }^{32}$ Ibid. p.33.

${ }^{33}$ Ibid., pp.1-5, quotation on p.4.
} 
the clergy to attempt to lay out a more explicit rationale for the provision of memorials of beauty. In so doing, they articulated sentiments that were often latent in the analyses of commentators such as Whittick. The Dean of St Paul's, W.R. Matthews, writing on the rebuilding of London in general and of ruined churches in particular, appropriated the language of commerce: 'Beauty and dignity cannot be given a cash value, but they are necessary elements in the good life and they bring in dividends which are not the less important because they are intangible and spiritual.' If it was the case that cities made by men reflected the state of their spiritual life, then only 'mean and ugly' cities could result from the work of those whose thinking was mean. A unique opportunity had arisen to make the new London worthy of the spirit of those who fought the Battle of Britain and the Battle of London.' ${ }^{34}$ George Bell, as Chairman of his conference, concluded that, whilst the promotion of the welfare of man was important, 'it was wrong to be content with a religion of humanity. The importance of beauty as beauty, and the need of loyalty to a noble expression of spiritual qualities must be emphasised.' 35 As Bell told the Lords, this was an opportunity to spread the love of beautiful things 'by way of victory over the war.' The subject matter should not only include the armed forces, but also 'scenes and monuments of peace', to include celebrations of law, education, poetry or religion: 'the very possessions and treasures which victory will have saved for our children and for posterity.' 36

Bell's rhetoric was however no simple repetition of the belligerent religious patriotism characteristic of the First World War, as his more unbuttoned rhetoric given to Christian audiences demonstrated. His guidance to his diocese on the planning of memorials (a document subsequently circulated to all the bishops at the agency of Archbishop Fisher) struck a relatively conventional note, the note of thanksgiving to Almighty God for deliverance from the

\footnotetext{
${ }^{34}$ Hugh Casson (ed.), Bombed churches as war memorials (1945), Foreword.

${ }^{35}$ 3rd page.

${ }^{36}$ Hansard (14/2/45) c.1043-4.
} 
gravest danger which our country has ever known, and for victory.' 37 A later sermon, at the unveiling of a new memorial in a Sussex church in May 1948, developed his theme rather further. Far from a simple struggle against a tyrannous Germany, the war had been 'a battle not of nations but of faiths, between Truth and Falsehood, Freedom and Tyranny. Had all the believers in Truth and Freedom, on both sides of the international conflict, stood firm by one another between the two wars, Europe and the world would be very different places today.' The task now was the building of a genuine peace, but one still far from complete, for ' $[\mathrm{u}]$ nless national life and international relations, unless economic systems and social order, are based on truth and justice, ruin and misery are bound to result. 38 For Bell, the creation of beautiful memorials, and what that implied about the nature of art, was an integral part of the struggle to recreate a European Christian civilisation that had been so disastrously lost.

What did this stress on the necessity of beautiful memorials imply about the style in which they should be executed ? There emerged a clear consensus, amongst both clerical and lay voices, on conscientiousness of execution, driven at least in part by a widespread sense of the inadequacy of many of the memorials of the previous war. In his guidance to the diocese of Canterbury, Geoffrey Fisher noted 'only too many examples up and down the country of memorials which while serving no social purpose, fail to serve a spiritual purpose by their mediocrity.'39 Viscount Samuel noted many 'lamentable' memorials, particularly from the Boer War, 'usually the figure of a private soldier in a very bellicose attitude, apparently carved by the local monumental mason. ${ }^{40}$ Both the War Memorials Advisory Council and the various diocesan guidelines urged the seeking of professional

\footnotetext{
${ }^{37}$ Chichester Diocesan Gazette vol. XX (wartime series 55), March 1945. A letter from Bell's chaplain to Fisher's office is at LPL MS Fisher 37 f.327. F.C. Eeles was at the same time arranging for its circulation to all Diocesan Advisory Committees.

${ }^{38}$ Sermon at West Hoathly 2/5/48, at LPL MS Bell 348, ff.51-2.

${ }^{39}$ Draft of article for Canterbury Diocesan Leaflet, at LPL MS Fisher 37, ff.334-5.

${ }^{40}$ Hansard 14/2/45 c. 1029.
} 
advice to avoid a repetition. Even on the question of lettering, the work of Eric Gill and others had convinced Lord Lang that it was 'useless to trust a thing so important to local tradesmen.' ${ }^{31}$

Did this concern for quality of craftsmanship imply an emphasis on contemporary, modernist style ? Jay Winter has suggested that in the period after 1918 traditionalism in style was to a degree psychologically necessary to the success of memorials. ${ }^{42}$ In contrast, after 1945, most commentators were able at the least to stress a necessary, if general, connection between contemporary style and the success of a work. Arnold Whittick stressed that 'a memorial, like any work of art, is dependent on the spirit of its age; if it is to have life it must be the creation of its age and must not be borrowed from the past. ${ }^{33}$ However, most of the earlier battlefield memorials cited by Whittick as exemplars, such as the Menin Gate or Sir Edwin Lutyens' Somme memorial at Thiepval, drew heavily on classical styles. ${ }^{44}$ The executed instances of memorial art by artists who would be considered as modern were in fact relatively few. In 1947 George Bell was involved in attempting to introduce the German Jewish refugee sculptor Benno Elkan, hard at work on a memorial sculpture to the effect of war on civilians, both to St Paul's and to the War Memorials Advisory Council, but to no avail. ${ }^{45}$ It was to be over a decade until Jacob Epstein was to be commissioned to place a memorial figure in the courtyard of Congress House, the London headquarters of the Trades Union Congress. ${ }^{46}$

One example of a memorial by a modern artist which was used in a church context was the 'Madonna and Child' by Henry Moore for the

\footnotetext{
${ }^{41}$ Hansard 14/2/45 c. 1039 .

${ }^{42}$ Winter, Sites of Memory pp.115-6.

${ }^{43}$ Whittick War Memorials p. 12

${ }^{44}$ Whittick, War Memorials pp.35-7. Whittick acknowledged an overdependence on Roman Doric at p.37.

${ }^{45}$ Bell to W.R.Matthews (Dean of St Paul's) 17/7/47 at LPL MS Bell 151, f.75; Bell to A.R.N. Roberts (War Memorials Advisory Council), undated, at LPL MS Bell 151, f.144.

${ }^{46}$ Commissioned in 1955, it was unveiled in 1958. Richard Cork, Jacob Epstein (London, Tate

Gallery, 1999) pp. 72-4; June Rose, Daemons and Angels. A life of Jacob Epstein (London, Constable, 2002), pp.261-3.
} 
church of Claydon in Suffolk. ${ }^{47}$ Commissioned by the historian and sometime chairman of the trustees of the Tate Gallery, Sir Jasper Ridley, in memory of his son and three others from Claydon, it was unveiled in December 1949. Based on one of a set of maquettes made by Moore for an earlier commission for the church of St Matthew, Northampton, its story is connected with the other most prominent name in Anglican patronage of the arts of this period, alongside George Bell: Walter Hussey, Vicar of St Matthew's and later Dean of Chichester. Ridley had been present at the meeting when Hussey, as patron, had settled on the final design for the Northampton sculpture ${ }^{48}$ and it was Hussey who was asked by Ridley to preach at the unveiling of the Claydon figure. Perhaps, Hussey suggested, it might have been thought that a sculpture in a traditional style would have been most fitting for the occasion, but Moore had 'aimed at expressing in stone something of what Christ means to us today'. A conventional statue may have been fit for a short time, but the Moore was a 'much more worthy memorial of your beloved fallen, something which will mean more to you every time you look at it, something which even the simplest among us will grow to understand more and to love better as the months and years go by. ${ }^{49}$ Only a living, vital piece of genuinely contemporary art could engage the imaginations of contemporary people.

The imaginative possibilities of the siting of memorials within or near churches, and indeed of churches themselves as memorials, gave rise to a number of suggested schemes. Herbert Baker advocated the siting of memorials with a regard to a sense of place, since "war or other memorials lose much of their spiritual value and appeal if they are not placed in sites already hallowed by past associations or where those

\footnotetext{
${ }^{47}$ On the prevalence of the Pieta in post-1918 memorials, see Winter, Sites of Memory pp.90-1.

${ }^{48}$ Roger Berthoud, The Life of Henry Moore (second edition, London, de la Mere, 2003) pp. 213, 259. Hussey's work is described in his own Patron of Art. The Revival of a Great Tradition Among Modern Artists (London, Weidenfeld and Nicolson, 1985). On Moore, see pp.23-48.

${ }^{49}$ The sermon is at WSRO MS Hussey 119, dated 18th December 1949.
} 
associations can grow in the course of the years. ${ }^{\prime 50}$ He saw in 1944 an opportunity to revive a memorial plan of his for Westminster Abbey, which had been unfulfilled after 1918. It should surely be a scandal if 'the central shrine of the English-feeling world possessed no memorials to our leaders who helped us to win the immortal glory which we are now confident will be the outcome of the war.'51 In 1942 a committee of the Royal Academy had formulated one of several schemes for a redevelopment of the ruined areas around St Paul's cathedral. ${ }^{52}$ This plan was subsequently proposed by W.H. Ansell, a past president of the Royal Institute of British Architects, as a national memorial. A sequence of tiered gardens stretching south to the river were suggested, along with pavilions with artistic depictions of 'a story of a great national deliverance', and an open-air altar would provide the focus for outdoor memorial services. ${ }^{53}$ Bell, asked by the Dean of St Paul's for suggestions for a memorial to the civilian victims of the Blitz, imagined a paved area with inlaid names, leading the pilgrim into the cathedral and towards a memorial sculpture, placed in the bombed north transept. 54

Despite this interest, in discussions about civic memorials (as distinct from those for individual congregations), clergy were often ambivalent about the degree to which they should be seen to be 'interfering', in contrast to the assertiveness evident after 1918. It was only on the strength of Herbert Baker's views that Bell felt able to suggest to the Lords that those responsible for larger memorials might be guided towards siting them in the environs of the cathedrals. ${ }^{55}$ At the same time Bell, whilst making much the same point in his diocesan gazette, felt the need to stress that, whilst the church should involve itself in

\footnotetext{
${ }^{50}$ Baker, Architecture and Personalities (London, Country Life, 1944) p.93.

${ }^{51}$ Ibid., p.106.

${ }^{52}$ On the schemes for the rebuilding of the area around St. Paul's, see Simon Bradley, 'The precinct and setting of St. Paul's from the $19^{\text {th }}$ century' in Derek Keene, Arthur Burns and Andrew Saint (eds), St. Paul's: the Cathedral Church of London, 604-2004 (New Haven, Yale University Press, 2004) pp.439-50; pp.444-6.

${ }^{53}$ W. H. Ansell, 'A suggestion for a national war memorial' Country Life 27/10/44 722-4. The plan was reproduced and discussed by Whittick, War Memorials pp.15-16, 32.

${ }^{54}$ Bell to W.R.Matthews 22/6/45, at LPL MS Bell $151 \mathrm{ff.298-9.}$

${ }^{55}$ Hansard, 14/2/45 c. 1042-4.
} 
local discussion, 'in no circumstances should it attempt to assert a claim for control. 56

Perhaps surprising in their rarity were bombed churches that were rebuilt whilst incorporating the ruins as memorial spaces. ${ }^{57}$ Perhaps the most famous single example is Coventry cathedral, of which the Manchester Guardian declared that 'there is not in Christendom a war memorial to match this. ${ }^{58}$. A related idea, which instead appeared to have found its moment in 1944, was the institution of the ruins of bombed churches as memorials, without rebuilding; particularly in the City of London but also elsewhere. These were memorials that would be at once beautiful, provocative of thought and of practical use to City workers. The idea was floated in the Architectural Review in January 1944, and a letter appeared in the Times in August of the same year, signed by establishment figures including Kenneth Clark, Lord Keynes and David Cecil, as well as T.S. Eliot and the architect H.S. Goodhart-Rendel. For those churches that had been very severely damaged, the proposal was made that, instead of their being either restored in an inappropriate pastiche of their former style or being replaced by an entirely new building, they should be left as they stood. In a relatively short time, the proposers predicted, the City would be rebuilt and no trace of the prime battlefield of the Home Front would remain. At such a time 'the story of the blitz may begin to seem unreal not only to visiting tourists but to a new generation of Londoners.' Whilst serving as sites of relaxation and meditation in the heart of the city, such churches would also fulfil the prime function of a memorial: 'to remind posterity of the reality of the sacrifices upon which its apparent security has been built. 59

The idea also made it beyond the opinion columns. Provision for such a scheme was made in the 1943 plan for the rebuilding of Plymouth,

\footnotetext{
${ }^{56}$ Chichester Diocesan Gazette vol. XX (wartime series 55), March 1945 p.3

${ }^{57}$ Hewitt, 'Sceptical generation' p.84.

58 'First hymns from new cathedral. Builders' thanksgiving' Manchester Guardian 1st Jan 1959.

${ }^{59}$ Times 15 August 1944 p.5.
} 
and in 1945 the architect Hugh Casson published a pamphlet with sketch plans for several of the City churches. 60 The Plymouth scheme involved leaving the ruined Charles Church, with its walls 'proudly upreared, defying both enemy and elements' to become a 'centre of historic interest and pilgrimage, an undoubted addition to the city's treasure of memories.' 61

Not all the establishment agreed with the idea. Sir Herbert Baker argued that whilst a war memorial should lift the mind to the hills of loving remembrance', a ruin could only 'lower them to the inferno where hate and revenge dwell.'62 It was also the case that, despite Archbishop Lang's advocacy in the House of Lord's, there was comparatively little clerical support for the idea. Geoffrey Fisher, as Bishop of London, had begun the process of planning what to do with the ruined City churches as early as 1941, but this particular idea gained little traction. ${ }^{63}$ Despite the presence of a canon of St Paul's, F.A. Cockin, as a signatory to the letter to the Times, George Bell, as the bishop delegated to take the matter of memorials forward, does not seem to have engaged with the idea. Among those who joined the correspondence in the Times were two of the City clergy, supporting Baker's protest. ${ }^{64}$

The lukewarm reception of the idea amongst clergy is probably reflected in the small number of examples of such schemes actually executed. Many churches were temporarily used as open-air spaces for worship, but either rebuilt or cleared in the fullness of time.

\footnotetext{
${ }^{60}$ Casson (ed.), Bombed Churches

${ }^{61}$ J. Paton Watson and Patrick Abercrombie, A Plan for Plymouth. The report prepared for the City Council (Plymouth, Underhill, 1943) p.16.

${ }^{62}$ Times 22 August 1944 p.2

${ }^{63}$ Fisher's Commission on the City Churches met once in October 1941, but appears to have foundered amidst some confusion over its role. There is no sign of the idea of ruined churches as memorials in the initial activities, as documented at LPL Fulham Papers, Fisher, volume 8 ff.250-354. On the collapse of the Commission, see Edward Carpenter, Archbishop Fisher. His Life and Times (Norwich, Canterbury Press, 1991) 83-4. The reconstituted Commission finally reported in 1946, discounting the idea in favour of selling the sites. The City Churches. Final Report of the Bishop of London's Commission (London, Church Assembly, 1946) p.12.

${ }^{64}$ The two were Everett Turner (St Giles Cripplegate) on 24/8/44 and Arthur G.B. West (St Dunstan in the East) on 25/8/44.
} 
Plymouth St Andrew, after several years as a 'Garden Church' was eventually restored, beginning in 1949, and reconsecrated in 1957.65 Of the City churches mentioned by Hugh Casson, only three appear to have been laid out with garden schemes, and one of those (Christ Church, Newgate Street) not until 1989.66 The ruins of All Hallows by the Tower, which were used as the frontispiece to Casson's work were in fact rebuilt entirely between 1949 and 1957.67

$* * * * * * * * * * * * * *$

It may reasonably be asserted that by the mid-1950s the dominant mode of commemoration in Britain was through 'useful' memorials. The foundation in 1946 of the National Land Fund as a national memorial 'better than any work of art in stone or in bronze' has been regarded as emblematic of this general trend. ${ }^{68}$ However, the history of the processes by which public and expert opinion was translated into physical form remains as yet mostly unwritten. Much work has been done on the processes by which memorials came into being after 1918, and the complex negotiations that took place between local elites, the public and their artists. ${ }^{69}$ The task of investigating this has yet to begin in earnest for the period after 1945 .

The choice of 1947 as the later limit on the scope of this article is thus a very deliberate one. It represents the stage at which discussions about memorials in principle had begun to die down, and the messy

\footnotetext{
${ }^{65}$ The restored church attracted attention for its stained glass by John Piper, at the same time engaged with work for Coventry Cathedral: 'Brilliant design for church window' Times 8 Nov 1957 p.12.

${ }^{66}$ Casson included plans for (in the City): St Vedast Foster Lane; St Swithin Cannon Street; St Alban Wood Street combined with St Mary Aldermanbury; Christ Church Newgate Street; St Mary-le-Bow; St Dunstan in the East. The site of the churchyard of St Swithin's is now marked with a garden. The site of St Mary Aldermanbury incorporates a garden, whilst the church itself was reconstructed in the USA. St Dunstan in the East has a garden and fountain, dating from 1967-71. Simon Bradley and Nikolaus Pevsner, The Buildings of England. London 1: The City of London (London, Penguin, 1997) 213-4, 413-4, 443.

${ }^{67}$ Buildings of England 184-6.

${ }^{68}$ The phrase is of Hugh Dalton, in his 1946 Budget speech; Times 10 April 1946; Cannadine, 'War and Death' p.233-4; Mosse, 'Two World Wars' p.504.

${ }^{69}$ See Winter, Sites of Memory pp.86-90; King, Memorials pp.106-27.
} 
business of commissioning, designing, raising funds for, and executing those memorials was beginning. In Bell's own diocese of Chichester, it was from 1947 onwards that the applications for faculty permission for new memorials or alterations to existing ones began to be submitted. ${ }^{70}$ At Coventry cathedral, the same year saw the appointment of the commission headed by Lord Harlech to consider the rebuilding of the cathedral, and the decision on Basil Spence's design was not finally taken until $1951 .{ }^{71}$

The present article has confined itself to a consideration of the moment during the last years of the war and immediately after, during which the interlocking ecclesiastical, artistic and governmental establishments began to envision the general shape of memorialisation. It has attempted to show that there had been a much more lively debate on memorials than the eventual inventory might imply. It also suggests that, at least amongst this 'establishment', the experience of the war was by no means a straightforwardly secularising influence. Clergy, artists and architects and the committees and bodies that facilitated their interaction were keenly interested in the relationship between beauty, utility and Christian civilisation, and their interaction reveals much about the broader relationship between the Church of England and the wider 'establishment' in this period.

\footnotetext{
${ }^{70}$ WSRO, Episcopal Records Ep I/98 (Faculty Papers), list of contents.

${ }^{71}$ R.T. Howard, Ruined and Rebuilt. The Story of Coventry Cathedral 1939-1962 (The Council of Coventry Cathedral, 1952) 38, 44.
} 